Received: Mar 27, 2020; Accepted: Apr 17, 2020; Published: Jun 05, 2020; Paper Id.: IJHRJUN20207

\title{
INTRODUCTION
}

The word Blitzkrieg is formed out of two German words; blitz for 'lightning' and Krieg meaning 'war.' This word has mostly been used to portray a technique of a focused and attacking combat intended to hit the enemy with a quick and calculated blow using active and mobile forces, particularly armour and air support. The fundamental aspect of this tactic was swiftness and surprise. Essentially, the theories of mobile tactics and holistic armed conflicts which evolved in Germany throughout the interwar period and the Second World War have been understood as the blitzkrieg strategy by most military historians. Operationally, the goal was to speedily inflict defeat on an adversary defeat in a decisive and short war fought by an optimum sized skilled army while limiting the loss of soldiers and weaponry. In order to achieve this objective, large independent cluster of tanks and mechanized infantry, artillery, engineering assets and sufficient air support were required to work in tandem. It can be said that the initial basic doctrine of such operations was conceptualised in the previous century by different countries. After the German defeat in the World War I, the concept was picked up by the German Wehrmacht, which attempted to work out a method of integrating the latest weaponry with transport assets. The objective was to deny any possibility of linear battles and trench warfare to emerge in the future battlefields.

The word blitzkrieg however gained acceptance as a description of the triumphant tactics used by the German Army in the first year of the world war-II, as they brushed aside Poland, Norway, Holland, Belgium and France with ap- 
parent ease and precision.

\section{Evolution of the Concept}

The defeat in World War I was a bitter pill to swallow for Germany. Most of their military strategists could conclude that the absence of movable forces and innovative plans took the war on its western borders to degenerate towards the grinding trench warfare. Many in Germany clearly thought that any future conflict would have to be shorter and in order to triumph, flexible military maneuvers were required.

The contours of the Blitzkrieg as a tactic for war had begun to clearly emerge in the inter-war years in German think-tanks. One of its leading proponents was General (later Field Marshal) Heinz Guderian who produced a book, Achtung Panzer, shortly before World War II, which also caught the eye of Adolf Hitler. Guderian was a military leader who knew how to combine new technology with the traditional German approach to warfare.

He propounded the theory of emerging victorious in combat with a strategy which encompassed swift progress of concerted mechanized troops aided by close air support. In the entire early period of the war, the mastery and innovation of his tactics were aptly displayed; from the combined-arms river crossings and incursions during the proceedings in France in 1940 to enormously extensive military incursions in Soviet Union in 1941.

\section{Evolution of the Tactics}

In the wake of defeat in the First World War, the new Reichswehr (the military organization of Germany from 1919 to 1935) formed groups of veteran officers to appraise some 57 issues related to the war. These groups then submitted their reports which were instrumental in setting up such doctrinal and teaching publications which germinated into the principles in the Second World War. These guiding principles which emerged had a lot of influence of the pre-war German military understanding about the penetration maneuvers of the war, which have been termed as Bewegungskrieg, or movement war. Bewegungskrieg necessarily made it essential that most decisions related to the fighting be made at the combat level and a new command hierarchy be evolved to facilitate this. This enabled all components of the forward troops to respond faster and quickly take effective decisions, which gives a definite edge in a battle scenario. This command structure contributed to the success of Blitzkrieg.

When we go back to the previous century of German military history, it emerges that the advocates of maneuvre, mass, and encirclement tactics were Carl von Clausewitz, Alfred von Schlieffen and von Moltke the Elder and their ideas were appealing and successful in the victorious Franco-Prussian War. In the aftermath of the World War-1, such ideas seem to be altered by the German Military planners when it was realized that the theory of excessive focus on encirclement propagated in the past had had its day. It was suggested that carrying out breach through the adversary's centre could be more a better substitute to encirclement. It was argued that in modern warfare, a small cohesive force was more competent of successful offensive action, and at the same time was less costly to maintain with additional up to date arsenal. This new doctrine was a contemporary revision of the existing system of "Bewegungskrieg" and its related tactical classification called "Auftragstaktik" or mission-type tactics, and the improvement of these resulted in the theories of offence associated with blitzkrieg. The core of these new tactics emanated from the penetration campaigns effectuated by the German Army during the First World War. In these campaigns, specialized German infantry had moved forward in optimally sized, cogent and decentralised units which went around the enemy forces or went through the weak points and then attacked it in the rear-area. The well directed ground shelling and air bombardments would then be followed up by regular infantry 
forces, which smashed all hubs of confrontation. The basis of the Wehrmacht's blitzkrieg tactics during the Second World War somewhat emanated from these strategies.

The World War-1 got pinned down into dugout combat in the trenches, in the entire western front of Germany and this weighed heavily in the minds of the military strategists of Western Europe, particularly France. However this did not happen on Germany's Eastern Front, where Russian and German armed forces clashed in a war of movement stretching over hundreds of kilometers, which gave the German military an exclusive and distinctive experience which was unavailable to its opponents in the Western Europe. The analysis of this unique experience seemed to suggest that small-sized, compact and harmonized troops were more capable of achieving results than large uncoordinated forces.

The other factors which impacted its evolution are discussed below:

\section{a) Foreign influence on Blitzkrieg}

The period between the two world wars saw the growth of motorized forces and consequently all major combatants developed theories based on mechanized forces. The French, British and American doctrines generally preferred extra set-piece encounters, fewer collective weapons usage, and a lesser amount of focus on concentration. These theories were studied in Germany and the Reichswehr periodicals in the twenties decade contained numerous examples of publication of these efforts translated in German. Most of these works remained in the publications and not adopted by the military. Some of the theorists however, did seem to suggest the idea of massive usage of tanks and aeroplanes.

In France Col. Charles de Gaulle was one such believer of massing the armor and tactical usage of aircrafts. Many historians claim that his views did, to some extent, had some sway on Heinz Guderian.

Similarly in England military strategists J.F.C. Fuller and Captain B. H. Liddell Hart, both proponents of fast moving armoured warfare are seen to be proponents of the idea of 'blitzkrieg'. Both Fuller and Liddell Hart clearly developed plans for enormous, self-sufficient tank maneuvers which were afterwards analysed in Germany. It is as expected put forth that Fuller's wartime plans and post-war writings did inspire some German theorists, and some suggest Guderian too.

The German and the Soviet Red Army collaborated in holding of joint war games and tests in Kazan and Lipetsk since 1926. In these years, the Red Army was in process of being restructured in hierarchical and doctrinaire terms and the period saw new theories emerging with the changes in technology. These collaborations were carried out in the Soviet Union, covertly, to circumscribe the restrictions imposed on Germany in the Treaty of Versailles for developing tanks and aircrafts. A number of field tests involving aircraft and armored vehicles were carried out at these locations. The officers of both armies were trained in the aerial and armored warfare schools.

\section{Field Marshal Heinz Guderian}

The period of the 1920s saw a massive study of the changes to be brought into military strategies and set-up in Germany. During this period, Heinz Guderian, later Field Marshal, become known as a powerful advocate of motorized forces who considered the tank as the vital weapon of war. He is said to have written an article addressed to detractors of tank oriented battles, that "until our critics can produce some new and better method of making a successful land attack other than selfmassacre, we shall continue to maintain our beliefs that tanks-properly employed, needless to say-are today the best means available for land attack." Later one of his most crucial suggestions was that radios be given to all tanks to facilitate co-ordination and command. It had a great impact in the battles which followed. 


\section{b) Panzertruppe and Luftwaffe}

The Treaty of Versailles limited Germany's standing army to 100,000 soldiers, completely barred the growth of numbers and quality of tanks and break up its air force. When the Nazis captured power in 1933, Adolf Hitler refused to abide by these provisions and went about expanding the army. Armored troops called the Panzertruppe was formed as a separate command within the German Wehrmacht; this was to be a game changer in the early part of World War-2 as dedicated tank regiments was not a norm till that time. This was followed by the rebuilding of the Luftwaffe, and strategies relating to ground-attack aircraft and dog fights were formulated. Hitler had also read Guderian's book Achtung! Panzer!and saw this as a breakthrough concept. Once while viewing armored field exercises at Kummersdorf, he reportedly remarked "That is what I want—and that is what I will have."

\section{c) Spanish Civil War}

The Spanish Civil War of 1936 provided the Germans a perfect opportunity to test all their theories developed after the World War-1 in actual battle conditions. The training to the nationalists and delivery of weapons to them ensured maximum exposure to new doctrines. Armoured vehicles and tanks were deployed in large numbers and the Luftwaffe arranged for the Nationalist forces squadrons of fighters, dive-bombers, and transports as the Condor Legion. A training centre for Nationalists was also arranged for which a force built around three companies of PzKpfw I tanks constituting Panzer Battalion 88 began functioning. Thus, both tactics and hardware were deployed and tested in combat, including the first operational action of the Stuka dive bomber in a real war situation.

\section{FEATURES OF BLITZKRIEG}

The blitzkrieg actions essentially involved a high level of tactical movement rather than abrasion, with pooled weaponry of mobile assets massed at a central position, i.e., Armour strongly aided by mechanized infantry and artillery with closely coordinated air support in order to defeat an opponent. These tactics inevitably called for an improvement in dedicated support transport, latest forms of communication, fresh and innovative methods of employment with an efficient structure ensuring command at decentralized level. Thus a motorised infantry, mobile and self-propelled artillery and technological assets that could sustain and consolidate the gains made with the advance of the tanks into enemy territory were required. It often involved avoiding direct combat with the enemy while disrupting the opponents' lines of communications, ensuring speedy decisions, efficiently managing the supply and other provisions along with impacting the morale of the enemy.

To put these tactics in action, the weakest part of the defences of the opposing army had to be identified first. Then a large armoured force was required to be tactically employed at these parts. The logistical, communication, and supply targets would be subject to aerial bombardment and the field artillery would strike hard at security installations of the enemy. This would enable the strongest part of the attacking force led by the armour to break inside the weak spot of the opponent. Once an opening was made by the tanks, the motorized infantry could be in a position to follow their armoured spearhead and fan out deep into the enemy's rear. They would then mop-up the enemy forces which were now surrounded by the tanks and mechanized infantry divisions. They would also try to quickly control all strategically vital goals like bridges, airfields, supply depots, rail yards, naval ports, and radar installations. The key element in this tactic was speed and the sudden incursion and aerial attacks would cause sufficient disorder and uncertainties in the enemy lines. The flanks would now be in the open which would then provide enough breakthroughs with the enemy army's major strongholds and their city areas being enveloped in expansive pincer engagements. Thereafter the regular, non-motorised infantry 
would deal with annihilating the remainder enemy resistance.

Thus the suddenness of movement which would stun and shock the enemy troops was a hallmark of the blitzkrieg operation. Its success owed much to the flexibility and volatility of the battlefield environment and the training, initiative and flexibility of its officers present on the theatre of war. Surprise was accentuated by swift movements inside the opposition's frontlines (especially at night), strategic control in the air, and some degree of self-support of the mechanized units (fuel enough for 150-200 kilometers of movement, nine days worth of ammunition and rations etc). The blitzkrieg operations were not necessarily reliant on more advanced tanks to emerge victorious. In fact, German tanks on average were not superior to French tanks in 1940, and faced many superior quality tanks in Russian, and African campaigns. French army had formidable artillery and over 3000 tanks on the north east front which was some 800 more than the Germans. Despite having an advantage in the numbers, the allies chose not to attack. The mindsets of the Allied military planners were stuck in the static warfare tactics of the world war-1, making them unprepared for the radical, innovative style of warfare which the blitzkrieg onslaught forced upon them.

The blitzkrieg was attractive for the German military strategists for another important though lesser known motive: it was incumbent to swiftly overcome the enemy forces before the war put a drain on an economy not yet on a war footing. In fact Germany had not bargained for a war with the Western European nations when it attacked Poland. The modernization plans of its armed forces were underway and were projected to reach desired levels in 1942-43. The German Navy was in its rebuilding stage and was projected to reach its potential by mid-1940s. Blitzkrieg solved the crisis of deficient industrial capacity and reserve of material essential for fighting a long-drawn-out war. The blitzkrieg tactics were applied by the Germans to astounding achievements in Poland (1939), France (1940), Russia (1941), and to some extent later in the Ardennes (1944), although in the strict sense, proper blitzkrieg a la Guderian was applied in the first two campaigns (Guderian was afterwards dismissed for disagreeing with Hitler's assessments in Russia).

\section{Blitzkrieg in World War II}

Spanish Civil War in 1936 had provided the German forces an opportunity to employ some of the procedures and tactics linked with blitzkrieg. The war began with the invasion of Poland in September 1939 and this tactic was tested in the 18 days leading to the surrender of Poland. During this period, aided by the air supremacy the Panzer tank divisions relentlessly forged ahead to swiftly subdue the fighting Polish Army. Thereafter in April 1940, neutral country Norway was invaded, and quickly occupied, in a string of shock attacks.

When Germans invaded Belgium and the Netherlands at dawn on 10 May, it was part of the plan to hoodwink the Western Allies who were convinced that the Germans were going to repeat of their strategy of 1914. This made them move the majority of their armies away from the Franco-Belgian border into protective points inside Belgium expecting the continuance of the German thrust as in the World War 1. This was the trap planned for them by the Germans. They knew that the French had built this huge defensive system called the Maginot line on the Franco German border which would have been impossible to breach and then they would have gotten into the hopeless bloodshed of trench warfare of the kind which happened in World War-1.

Thus displaying an out of box initiative, the German thrust came through the Ardennes Forest as they avoided repeating the Schlieffen Plan of World War-1, with the main allied armies positioned on the Franco-Belgian border in the north. The Ardennes was the last place for an offensive thrust expected by the western allies. This then was the susceptible 
edge on the Allied lines which could be demolished to enable the blitzkrieg tactics to succeed.

However on 10 May, 1940, as 29 German divisions as part of Army Group B moved through the Netherlands and Belgium to execute a ruse in the north to lure the allied armies, French reconnaissance planes reported a huge traffic jam of tanks and other military vehicles, on the German side just across the Ardennes forest in the south. The allied military strategists, still living in the world war-1 mindsets, refused to believe that armoured thrusts could take place through the difficult forest terrain. They thought that this attack was the decoy and the main attack was in the north. Thus 45 German divisions, including about 2,400 tanks in 7 divisions, alongwith tanks, motorised infantry and artillery constituting the Army Group A, burst through the Ardennes Forest on a narrow front. Here they faced a feeble French defence, whose crack troops had been sent north, who were swiftly overcome and the Allied defenses were penetrated. A big boost to the German campaign accrued from the improved radio communications which allowed coordinating strategy amongst all their tanks as unlike the British and French tanks all their panzers were equipped with radios. This proved to be the central theme of their attack as it enabled all panzer commanders to coordinate the advance and prevented any stability to emerge in the enemy ranks. The German Air Force (Luftwaffe) had in the meanwhile achieved local air dominance and was in a position to support the ground attack.

The Germans then pierced through France towards the English Channel, forcing the British Expeditionary Force in a compartment at the beaches of Dunkirk from where they were evacuated to England. This defeat in the north and absence of any mobile reserves led to the defeat of the remaining French army, and it sued for peace leading to the Armistice of 22 June 1940. This campaign was portrayed as a model of the blitzkrieg strategy.

General (later Field Marshal) Erwin Rommel, who brilliantly led a Panzer division through the invasion of France, would subsequently employ the blitzkrieg tactics against British forces in the deserts of North Africa in 1941-42 with some success when he led the famed Afrika Korps.

When Hitler launched operation Barbarossa in June,1941, in their invasion of the Soviet Union, the German army again employed the blitzkrieg tactics with the understanding that this battle too, similar to the attack on France in the previous spring, would be a short one. However this was a completely different enemy and the vast size of the Soviet Union prevented quick victories, laying bare the shortcomings of the Blitzkrieg strategy.

\section{BENEFITS TO GERMANY IN WW-II}

In order to understand how the Blitzkrieg tactics played an instrumental role in the defeat of Germany's opponents, one needs to know that the allied armies were not lacking in the heavy armour at the beginning of the World War-2. The British and French tanks outnumbered the Panzers (German tanks) and the British Matilda and French Char tanks were in many ways superior to the Panzers. It was the management of the armoured forces and their deployment that made the Germans emerge superior. The British and French armies did not have dedicated tank divisions and they spread out their tanks which every infantry platoon being given a definite quantity of tanks. The German tanks were massed with about three or four hundred tanks comprised in Panzer divisions, which in battle conditions led to establishment of dominance over an infantry division with a small number of tanks playing a subordinate role. The Germans also possessed superior air power with more effective aircraft at this stage.

The key element in the war was the existence of surprise in the battle strategies. These key elements employed in blitzkrieg tactics came as a huge shocker to its opponents as they were not prepared for it. 
In addition to its tactical novelty, the proper implementation of Blitzkrieg strategies, along with some good fortune, also played a part in the German success in 1940. The sectors of attack were carefully chosen. It would have been suicidal to attack the 93 miles long Maginot line with its strong fortifications along the French-German border, manned by 400,000 men. The Allies never thought that the German attack would come from the Ardennes, a hilly region covered in woodland in southern Belgium, for it would not be possible to break through the impenetrable woods with tanks in large numbers. The Germans took the gamble and it could have gone horribly wrong had the allies targeted the German Army Group A when it was clustered on the road to Ardennes. But the French ineffectual leadership was too inflexible to gauge the threat and allowed the attack to proceed. The French only had some 100,000 improperly equipped, poorly skilled men at that sector, who could not stop the Germans army from charging through to the sedan.

As the invasion began, infantry tanks and artillery showed incredible levels of stamina. Barely stopping they reached sedan in three days. Many German soldiers did not sleep during these 3 days. The French defenses are unexpectedly confronted with 60000 rampaging Germans in 22000 vehicles and 850 tanks. After 3 days on the march the Germans had no intentions of stopping as they prepared to cross the river Meuse in 3 places. The speed of the breakthrough in 3 days was significant because any delay would have impacted the result negatively for the Germans because the 500,000 allied forces posted in the north might have arrived there to buttress the defense of Ardennes. The German military engineers, road builders, and demolition squads also played a significant role in effectuating the breakthrough while they simultaneously did away with the trees, laid bridges and roads in order to allow their army to move ahead in the difficult terrain. They ensured that the momentum was not lost as the Germans covered some 200 miles in 7 days. This further created a complication for the French in the form of almost 12,000,000 refugees who were walking all over France away from the German attacks. These created further confusion behind the lines for the allies and seriously jeopardized any counterattacks being proposed by the Allied High Command. To add to the confusion and disorganization, the refugees were constantly subjected to air attacks by the Luftwaffe. Psychological effect of the screaming dive bombers was devastating.

The German army had another secret weapon, manufactured by the Berlin drug co. called Temmler. Pervitin is a powerful methamphetamine known on the streets today as "crystal myth". Already sold as an over the counter drug in Germany, this medicine proved valuable in the theatre of war. Pervitin was seen as an ideal drug to combat fatigue. In the blitzkrieg in France, it is used specially for the panzer troops and for the night fighters; the troops that are always close to the enemy and have to remain active for a long time. Methamphetamine have a tendency to dull any feeling of empathy and make one feel superhuman which are the qualities required for creating a perfect soldier. Just before attacks started on 10 may 1940, there were a lot of soldiers who were depressed who didn't want to fight and who remembered the World War-1 and its trench warfare which had an effect on the morale of the Germans. Once methamphetamine was taken, the morale became quite high. This ensured the speed of movement of the troops and maintained the focus required for a very quick decisive battle.

The stunning German campaigns resulted in surrender of Holland on the 14th of May and Belgium on May the 27th. The British Expeditionary Force along with some troops of the other allied armies evacuated from Dunkirk on the 4th of June as they somehow managed to reach back to England bruised and battered. On June 22 the French government signed an armistice with Germany.

\section{Novelty of Blitzkrieg Warfare?}

The spectacular success achieved by Germany in its campaigns in Europe in 1939-40 led the Nazi propagandists and many 
in Western media to attribute it to an innovative and original form of fighting a war which was branded as "blitzkrieg". However a closer look reveals that despite the fact that "blitzkrieg" was used as a word to describe a short conflict in some German military writings in the pre-World War II period, and meant as different from a full fledged conflict of gradual grinding down, it lacked any formal acceptance as a military policy.

The invasion of Poland in 1939 saw a fair bit of use of the term blitzkrieg. But it is now generally held by historians that German operations in this campaign were more in line with the conventional ways of fighting. The strategy of the Wehrmacht resembled its long standing tradition of Vernichtungsgedanken, meaning the "concept of annihilation". Similarly in the campaigns in May and June 1940 many strategies engaged by Wehrmacht when the World War I began, which emphasized a quick victory for Germany, were mirrored. These were in line with the thinking propounded by Alfred von Schlieffen, the Chief of the General Staff of the German Army from 1891 to 1906, whose key objective was to win a short war as the country was ill-suited to emerge victorious in a long drawn out war against better-prepared forces.

Thus, Schlieffen argued that the German army could win by matching quantity with quality. In order to effectuate this thinking, Schlieffen propounded a principle of war in which the outnumbered German army would be able to overwhelm its adversaries. This proposed doctrine emphasized on momentum of maneuver and hitting hard at the adversary where it was weak. At the same time, he anticipated the need to sustain the initiative by forcing the enemy to react to German moves. This could be achieved through setting up a flexible command system which allowed independence of decision making at the level of the local commanders. Such a system was conceptualized earlier too by Schlieffen's predecessor, Helmuth von Moltke the Elder. Based on this method of directing the armies in a rapidly changing battlefield, the trend in the German army gravitated towards egging on its commanders towards making their own choices on the battlefield and not to look for orders from above. This saved crucial time in the battle and any opportunities which could have arisen could be quickly lapped up. In addition, this dogma fashioned bold and decisive leaders.

Schlieffen ensured that the concepts of what was phrased Bewegungskrieg, or 'war of manoeuvre' well entrenched in the German army and they were trained as per its principles. Helmuth von Moltke the Younger, carried forward the Schlieffen doctrine being his successor, but could not carry out the plan in the World War-1. In 1914, German units after initial successes lost the momentum, and got bogged down in the static trench Warfare. However the facet that was missing from the German army in 1914 was the capability of covering long distances rapidly as mechanization had not occurred at that time. One can reasonably assume a very different outcome for that war if it had been there. Germany's search for a method to end the grinding stalemate of the trenches continued through the World War-1. When their efforts to break the deadlock seemed to bear results, in the form of mobile units in the 1918 Spring Offensive, it was too late to change the outcome.

Some features of Blitzkrieg were displayed in the First World War by many commanders. General Alexei Brusilov of Russia conspicuously demonstrated some of these in Brusilov Offensive of 1916. Similarly Britain's General Allenby used armored vehicles and heavy artillery along with aerial bombardment in the Battle of Megiddo in September 1918, to earn a quick success. The 1918 Spring Offensive of the Germans had many elements of the blitzkrieg theories.

The crucial difference from the world war-1 situation was that by the advent of the fourth decade of the century, the German army could make use of an entirely new level of military know-how and equipments such as the tanks, motorised vehicles, attack airplanes and radios, which were developed or improved in the 1920s and 1930s. It was now possible to churn out a new modern variety of military assaults by mingling the use of these new weapons and gadgets with the 
strategy which emphasised swiftness, mobility, focused attacks and encirclements.

The perception of Allied military leadership which had been routed in France was that 'blitzkrieg' was dependent on the pervasive use of novel strategy and modern weaponry, particularly the tanks and dive-bombers. This view was formed out of the shock faced throughout the devastating battles in France and Belgium, where German tanks and aircraft seemed omnipresent. It can also be said that there could be no other way of explaining the reasons for the catastrophic loss. Sometime in 1939 by the American newsmagazine TIME describing the 1939 German invasion of Poland. Published on September 25 1939, well into the campaign, the account reads:

The battlefront got lost, and with it the illusion that there had ever been a battlefront. For this was no war of occupation, but a war of quick penetration and obliteration-Blitzkrieg, lightning war. Swift columns of tanks and armored trucks had plunged through Poland while bombs raining from the sky heralded their coming. They had sawed off communications, destroyed animal, scattered civilians, spread terror. Working sometimes 30 miles (50 km) ahead of infantry and artillery, they had broken down the Polish defenses before they had time to organize. Then, while the infantry mopped up, they had moved on, to strike again far behind what had been called the front.

This analysis that Western Europe in 1940 was won through a unique form of warfare by the Germans using technology, has to a large extent been the general perception. Nevertheless a closer scrutiny would reveal that blitzkrieg as a way of waging war had evolved over a period of time. Also there existed other factors which contributed to the German success.

In recent years more historical research and analysis of the war has tended to portray a more balanced view of the role of blitzkrieg. The understanding of operations in Poland has also modified by a long way since the Second World War. Latest historical researches classify German attack on Poland as rather guarded and conventional. Matthew Cooper in his book 'The German Army,1933-1945,' wrote that

"...(t)hroughout ( the Polish Campaign), the employment of the mechanized units revealed the idea that they were intended solely to ease the advance and to support the activities of the infantry....Thus, any strategic exploitation of the armored idea was still-born. The paralysis of command and the breakdown of morale were not made the ultimate aim of the ... German ground and air forces, and were only incidental by-products of the traditional maneuvers of rapid encirclement and of the supporting activities of the flying artillery of the Luftwaffe, both of which had has their purpose the physical destruction of the enemy troops. Such was the Vernichtungsgedanke of the Polish campaign."

He further added that the deployment and utilisation of panzers "left much to be desired...Fear of enemy action against the flanks of the advance, fear which was to prove so disastrous to German prospects in the west in 1940 and in the Soviet Union in 1941, was present from the beginning of the war." John Ellis emphatically added that "...there is considerable justice in Matthew Cooper's assertion that the panzer divisions were not given the kind of strategic mission that was to characterize authentic armored blitzkrieg, and were almost always closely subordinated to the various mass infantry armies."

In fact, "Whilst Western accounts of the September campaign have stressed the shock value of the panzers and Stuka attacks, they have tended to underestimate the punishing effect of German artillery on Polish units. Mobile and available in significant quantity, artillery shattered as many units as any other branch of the Wehrmacht.",

Thus in effect, this so-called blitzkrieg of 1940 was actually the earlier German doctrine with technology added 
on. The opening battles of World War II showcased the first practical implementations of this idea. The invasion of Poland went along the somewhat conservative line but the succeeding battles, right from the invasion of France, Belgium, Netherlands and opening incursions in the Soviet Union, were successful leading to astonishing penetrations in the enemy lines. The general unpreparedness of the enemy and its inability to react quickly to German penetrations were contributory factors. The swiftness of these victories gave the impression that a novel method of warfare had been invented.

However Germany's inability to annihilate the Soviet armies in 1941 before the advent of winter, pitchforked the limitations of German tactical control and dominance most visibly. This was despite the fact that the German invasion effectively subjugated and occupied huge chunks of Soviet territory. But the taken as a whole the strategic effects were limited. The sheer size of the Soviet Union allowed the Red Army to fall back repeatedly and reorganize itself deep behind the main battle line. Further, the military industrial production units were also taken to its interiors which were far beyond the reach of the Luftwaffe. The blitzkrieg tactics had no answer to this strategic depth and manpower reserves of the Soviet Union and failed to succeed against them.

\section{LIMITATIONS OF BLITZKRIEG STRATEGY}

\section{Logistics}

In many ways, the novelty of the strategy played a big part in the success it had in nippy tactical battles in the invasion of Poland and then Belgium and France. However even in the French campaigns, the issues of logistics had threatened to derail the German campaign, which was saved by a combination of various factors such as the unimaginative French leadership, the flexibility of the German military leadership on the ground and pure good fortune of the Germans. There always existed an innate peril for the offensive army overstretching its supply lines or infantry not being able to keep pace with the attacking panzers. These issues had plagued the campaign in France. Armoured Counter attacks by the French (led by the then Col. Charles de Gaulle) and the British had exposed the fragility of the overstretched German lines. The strategy as a whole would be in serious trouble against a determined enemy nation which unlike the smaller western Europe nations, had a larger territory and was prepared to withdraw and temporarily give up territory to gain time to recuperate and recover. This was the approach of the Soviet Union to the German invasion in operation Barbarossa and subsequent attacks in 194142. The German army was short on ideas to counter such a challenge. Again Blitzkrieg seemed to flounder against well prepared and structured defenses. All these logistical flaws were exposed in the German campaigns in the Soviet Union in 1941 and 1942 as major reverses were faced by the German armies and heavy casualties were suffered. These reverses forced the German army into defensive war on all fronts by 1943.

By the mid-years of the war the Anglo-American strategic bombing created critical shortages of fuel and materials related to production of tanks, aircrafts and vehicle for Germany. These affected the normal operations and it was not possible to launch blitzkrieg type of attacks with such shortages.

\section{a) Environment}

All the features and concepts related to the term "Blitzkrieg" -swift and substantial armoured penetrations, great encirclements along with collective arms assaults-required favourable terrain and weather conditions for achieving victory. In the battle scenarios which did not offer the rapidity of movement for the armour, the ability of the offence to succeed was doubtful. The Terrain such as hilly areas or those obstructed by natural barriers or fortifications, would subject the armour to vulnerability to defending forces in close-quarters combat and unable to make the crucial breakthroughs. The strategy could not have succeeded if the attack had commenced against the fortified maginot line. Weather had affected the re- 
sumption of the panzer thrust towards Dunkirk in late May, 1940. During operation Barbarossa, the untimely October rains thwarted the momentum of the German attack. The movement of the advancing forces could also be brought to a standstill by sludge or extreme. Artillery surveillance along with airborne support, other crucial pillars of support to the strategy of blitzkrieg were also obviously reliant on weather.

\section{b) Air superiority}

German forces enjoyed complete domination of the skies over France and Poland when it enjoyed the successes of blitzkrieg. The RAF didn't throw in their entire strength into the battle, at first assuming a long drawn out war of attrition and later on saving the planes for the defense of England. The Luftwaffe was thus able to enjoy complete air superiority which facilitated aerial reconnaissance and close air support to its ground forces. This allowed unfettered progress of the land forces which is central in the success of the blitzkrieg tactics. As the war progressed, this air superiority was lost to the Allies effectively ruling out any blitzkrieg type operations for the Germans. Operation Wacht am Rhein, said to be the last German blitzkrieg style assault of the war, was intended to take off for the period in which bad weather conditions prevailed in which the Allied aircraft could not operate freely. This operation, after initial success in overcast conditions, floundered later on account of, inter alia, returns of clear weather enabling the Allied air dominance to scuttle the German thrust. Under these conditions, it was the Allied commanders like General Patton, and not the Germans, who were utilizing the "armoured idea" to its anticipated potential.

\section{c) Counter-Tactics}

French defensive mindset of sticking to the preconceived notions emerging out of warfare strategies of quarter of a century ago, epitomized the effectiveness of Blitzkrieg against static defense doctrines. In the aftermath of his country's defeat, Polish general Stanisław Maczek, who commanded the $1^{\text {st }}$ Polish Armoured Division, analysed and reported in detail on working of a blitzkrieg campaign for the benefit of the French military. He utilized the experience of facing the onslaught to study its procedure, efficacy and probable safety measures. He proposed specific counter measures to throw the momentum of the attacks off-gear and thus gain time for countering the full invasion. However, the French staff did not take cognizance of this information (the report later fell unopened, into the hands of the German army). Afterwards, the same General Maczek as head of 1 Polish Army Corps under Allied command was among the best leaders of armored forces in the liberation of France in 1944.

Evidence to the effectiveness of the counter attacks was demonstrated in France in 1940 in Battle of Arras, when the French 4th Armour Division and the British 1st Army Tank Brigade in the British Expeditionary Force made prying assaults on the German frontline and managed to thrust into the rear of the moving armored columns at times. These forays managed to temporarily halt the progress of the advance and as this made the German High command wary of their overstretched flanks. The halt to the attacks on the $21^{\text {st }}$ of May consequent to the Battle of Arras, probably saved Dunkirk from capture by the $10^{\text {th }}$ Panzer Division before the evacuation of the BEF.

Later the Hedgehog defense tactic would emerge as a strong response to blitzkrieg attacks with mutually supporting strong points in depth in heavily fortified defensive positions, permitting enemy forces to penetrate between the defensive concentrations while each strongpoint continues to fight, using their own armored reserves to counter-attack and destroy the enemy advance after cutting them off from their support groups. A proper deployment of the artillery, particularly at the flanks, had the potential of severely punishing the aggressors and putting the attack in disarray. After the capitulation of France in 1940, the Allied forces utilized the experience gained therein to successfully develop these counter tactics, 
which characterized their later operations. The Battle of Kursk,1943, the counterattacks at the Falaise by the US and Canadian armies, amalgamation of hedgehog resistance at Bastogne, St Vith and more such positions at the Ardennes, and even the hedgehog defense undertaken by the Germans themselves against Soviet Winter advances in 1941-42, amply exemplified the limitations of the blitzkrieg tactics.

\section{Influence of Blitzkrieg}

Blitzkrieg's initial awe inspiring success was bound to impact the military thinking all over the world. It immediately jolted the opponents from the somnolence of the existing military thoughts emanating from the previous century. The military leadership of the Western Allies, who were impacted hugely in terms of military losses, studied and absorbed the elements of this strategy. One of the foremost among the military analyst was the dashing United States General George S. Patton, an exceptional exponent of aggressive tank warfare, who laid emphasis on swift chase, the utilization of an armored front to shape an infiltration in the enemy lines, then cut off and cause disruption in the enemy forces prior to their flight. He is said to have endorsed Guderian's and Rommel's work, notably Infantry Attacks, for impacting his views on this subject.

The Blitzkrieg impact has also been visible in successive military doctrines and operations. Defense Forces of Israel seem to be inclined towards blitzkrieg tactics which was seen in the putting together of independent armored thrusts supported closely by air-power, which they successfully deployed in the 1967 and 1973 wars with Egypt and Syria. The United States has variously used these "Shock and awe" theories in the 1990s in the middle East campaigns as part of their larger strategy of "rapid dominance". In the 1971 Bangladesh liberation war, the Indian Army utilized blitzkrieg tactics to quickly overrun the country by selectively engaging or bypassing heavily defended strongholds.

\section{REFERENCES}

1. Ian Carter, "The German 'Lightning War' Strategy of the Second World War."

2. Robert T. Foley, “Blitzkrieg.” $\underline{B B C}$.

3. Robert T Foley, German Strategy and the Path to Verdun.

4. Karl-Heinz Frieser, The Blitzkrieg Legend.

5. Oboegbulem, Angie Ijeoma, and Evelyn Ijeoma Ezepue. "Management Strategies for Conflict Resolution In Universities." International Journal of Educational Science And Research (Ijesr) 6 1, Feb 2016, 21 -32

6. David T. Zabecki, ed., Germany at War: 400 Years of Military History.

7. Wulandari, Rizka Maulina. "An Analysis Of Politeness Strategies In Emails Of Indonesian Efl Learners." International Journal Of English And Literature (Ijel) 8.3, Jun 2018, 79-94

8. Ahmed, Qazi Mohammed, AMARA AFZAL, and SABEEN ALI. "Analyzing Consumer Behavior Towards Brand Extensions." International Journal of Business Management \& Research (IJBMR) 5.6 (2015): 43-56.

9. Ranathunga, Gayathri Madubhani. "Learning Incubates Fashion: The Case of The Kandyan Kingdom of Sri Lanka." International Journal of Humanities and Social Sciences (IJHSS) ISSN (P) (2018).

10. Ali, Salimabarkat, and Anjum Ara. "Intelligence as a determinant of academic achievement: A comparative study of high achievers and underachievers." International Journal of Humanities and Social Sciences (IJHSS) 6.6 (2017): 79-88.

11. Septima, E. "A Study on the Characterizaton of Women in Shashi Deshpandey's Novels." IMPACT: International Journal of Research in Humanities, Arts and Literature (IMPACT: IJRHAL) 5.12 (2017): 1-6. 